Meta

Journal des traducteurs

Translators' Journal

\title{
Translating Musical Libretto: A Dynamic Collaboration
}

\section{Stella Sorby}

Volume 60, numéro 2, août 2015

$60^{\mathrm{e}}$ anniversaire. Les horizons de la traduction : retour vers le futur

$60^{\text {th }}$ Anniversary. Translation's Horizons: Back to the Future

60mo aniversario. Los horizontes de la traducción: regreso al futuro

URI : https://id.erudit.org/iderudit/1032922ar

DOI : https://doi.org/10.7202/1032922ar

Aller au sommaire du numéro

Éditeur(s)

Les Presses de l’Université de Montréal

ISSN

0026-0452 (imprimé)

1492-1421 (numérique)

Découvrir la revue

Citer ce document

Sorby, S. (2015). Translating Musical Libretto: A Dynamic Collaboration. Meta, 60(2), 371-371. https://doi.org/10.7202/1032922ar d'utilisation que vous pouvez consulter en ligne.

https://apropos.erudit.org/fr/usagers/politique-dutilisation/ 


\title{
Translating Musical Libretto: A Dynamic Collaboration
}

\author{
Stella Sorby \\ University of Portsmouth, Portsmouth, UK \\ stella.sorby@gmail.com
}

When translating musicals from one culture to another, a translator's role is to convert the libretto for its representation in a different context. However, during the process from this translated text to it finally being performed on stage, changes are inevitable. Issues surrounding the nature of such changes, the reasons for which they are made, and their resulting effects, have hitherto been little researched.

Based on the contemporary Chinese translation version of the off-Broadway musical I love you, you're perfect, now change, this paper seeks to explore such issues. It investigates the ways in which the development of the translated text is shaped by not only linguistic and theatrical factors, but also through interactions and collaborations between the various stakeholders, including translators and production team members, for example, the director and actors.

Employing Latour's Actor Network Theory (ANT) as the principal analytical framework, a stakeholder model is proposed to explain the process of musical libretto translation. Together with a case study approach combining textual analysis and empirical studies, it attempts to show how the potential for collaborative practices are expanded through the negotiations from differing stakeholder perspectives.

The findings suggest that, owing to the genre features of musicals, in addition to being concerned with the accurate resemblance between the source and the target texts in order to fit in with the musical framework, the translators operate in a dynamic network environment. They need to collaborate with the production team members, benefitting from the input of the expert knowledge of the latter, in order to produce the successful translation of a musical.

Stella Lanxing Sorby holds a BA (Hons) in Chinese Language and Literature from China and an MA in Translation and Interpreting from the UK. Her PhD in Translation Studies was funded by the Hong Kong Research Grants Council's prestigious Hong Kong PhD Fellowship Scheme. She worked as a journalist in China and as a Senior Lecturer in the UK. Currently she works as a consultant with Cambridge International Examinations (CIE) for examinations and teacher training. Her research interests lie mainly on translation between English and Chinese, especially in the fields of musicals, literature and news translation. She has published articles and papers in various journals including Babel. She is a Fellow of the Higher Education Academy in the UK; an Academic member of Institute of Translation \& Interpreting UK (ITI), as well as an Advanced Member of Translators Association of China. 